\title{
Paraoxonase- 1 activity and the levels of lipids and lipid peroxidation markers in arterial versus venous blood samples in coronary angiography patients
}

Aktywność paraoksonazy 1, poziomy lipidów oraz markerów peroksydacji lipidów w próbkach krwi tętniczej i żylnej u pacjentów poddawanych konarografii

\author{
Ayşe Yeşim Göçmen'1, Saadet Gümúşlứ2, llhan Günaydinn ${ }^{3}$ Ender Semiz ${ }^{4}$ \\ 1Department of Biochemistry, Faculty of Medicine, Bozok University, Yozgat, Turkey \\ 2Department of Biochemistry, Faculty of Medicine, Akdeniz University, Antalya, Turkey \\ ${ }^{3}$ Department of Internal Medicine, Faculty of Medicine, Bozok University, Yozgat, Turkey \\ ${ }^{4}$ Department of Cardiology, Faculty of Medicine, Pamukkale University, Denizli, Turkey
}

Postep Kardiol Inter 2012; 8, 3 (29): 199-204

DOI: $10.5114 /$ pwki.2012.30399

\begin{abstract}
Introduction: The percutaneous catheterization of various arteries is used in visualization of coronary arteries.

Aim: We aimed to determine whether arterial blood samples withdrawn from femoral arteries during standard Judkin's technique in patients evaluated with coronary angiography can also be used to determine some biochemical parameters.

Material and methods: In 50 controls ( 25 males and 25 females) and 73 coronary artery disease (CAD) patients (10 females and 63 males) paraoxonase-1 (PON1) activity, total cholesterol (TC), low-density lipoprotein cholesterol (LDL-C), very low-density lipoprotein cholesterol (VLDL-C), high-density lipoprotein cholesterol (HDL-C) and triglyceride (TG) levels were measured using colorimetric methods. Lipid peroxidation marker levels (conjugated dienes (CD) and thiobarbituric acid-reactive substances (TBARS)) were measured manually.

Results: There was no difference in lipid and lipid peroxidation marker levels, PON1 activity and TC/HDL-C, LDL-C/HDL-C and PON1/HDL-C ratios between arterial and venous blood samples. LDL-C, CD and TBARS levels and TC/HDL-C and LDL-C/HDL-C ratios were significantly lower in both arterial and venous blood samples of controls compared with CAD patients. Paraoxonase-1 activity, HDL-C level and PON1/HDL-C ratio were higher in controls than CAD patients. On multiple logistic regression analysis, risk factors associated with CAD were found to be the levels of arterial CD, venous CD, arterial TBARS and arterial LDL-C/HDL-C ratios in CAD patients.

Conclusions: Our study might indicate that arterial blood samples can also be used as well as venous samples to determine these parameters. On the other hand, elevated arterial lipid peroxides are associated with cardiovascular complications, presumably by decreasing PON1 activity.
\end{abstract}

Key words: paraoxonase, artery, vein, lipids, lipid peroxidation, coronary artery disease

\section{Streszczenie}

Wstęp: Cewnikowanie przezskórne jest wykorzystywane w obrazowaniu tętnic wieńcowych.

Cel: Określenie, czy próbki krwi tętniczej pobrane z tętnicy udowej u pacjentów poddawanych koronarografii standardową techniką Judkinsa mogą zostać użyte do oceny niektórych parametrów biochemicznych.

Materiat i metody: Przy użyciu metod kalorymetrycznych u 50 osób z grupy kontrolnej (25 mężczyzn i 25 kobiet) oraz u 73 pacjentów (10 kobiet i 63 mężczyzn) z chorobą wieńcową oceniono aktywność paraoksonazy 1 (PON1), stężenie cholesterolu całkowitego (total cholesterol - TC), cholesterolu lipoprotein o niskiej gęstości (low-density lipoprotein cholesterol - LDL-C), cholesterolu lipoprotein o bardzo niskiej gęstości (very low-density lipoprotein cholesterol - VLDL-C), cholesterolu lipoprotein o wysokiej gęstości (highdensity lipoproteid cholesterol - HDL-C) oraz triglicerydów (triglycerides - TG). Poziomy markerów peroksydacji lipidów [sprzężone dieny (conjugated dienes - CD) oraz związki reagujące z kwasem tiobarbiturowym (thiobarbituric acid-reactives substances - TBARS)] określono ręcznie.

Corresponding author/Adres do korespondencji:

Prof. Saadet Gümüșlű PhD, Department of Biochemistry, Faculty of Medicine, Akdeniz University, 07070 Antalya, Turkey, tel.: +90 242 2496896, fax: +90 242 2274495, 2274482, e-mail: sgumuslu@akdeniz.edu.tr

Praca wptynęła: 19.02.2012, przyjęta do druku: 3.08.2012. 
Wyniki: Nie obserwowano różnic w stężeniu lipidów i markerów peroksydacji lipidów, aktywności PON1 oraz ilorazów TC/HDL-C, LDL-C/HDL-C i PON1/HDL-C między próbkami krwi tętniczej i żylnej. Stężenia LDL-C, CD i TBARS oraz stosunek TC/HDL-C i LDL-C/HDL-C były istotnie mniejsze zarówno w próbkach krwi tętniczej, jak i żylnej u osób z grupy kontrolnej w porównaniu z pacjentami z chorobą wieńcową (coronary artery disease - CAD). Aktywność PON1, stężenie HDL-C oraz stosunek PON1/HDL-C były większe u osób z grupy kontrolnej w porównaniu z pacjentami z CAD. Czynnikami ryzyka związanymi z CAD określonymi na podstawie wieloczynnikowej analizy regresji logistycznej były stężenie CD we krwi tętniczej i żylnej, TBARS we krwi tętniczej oraz stosunek LDL-C/HDL-C w próbkach krwi tętniczej.

Wnioski: Badanie może sugerować, że obok próbek krwi żylnej także próbki krwi tętniczej nadają się do oceny analizowanych parametrów. Poza tym zwiększone stężenie utlenionych lipidów we krwi tętniczej wiąże się z powikłaniami sercowo-naczyniowymi, co jest prawdopodobnie warunkowane zmniejszeniem aktywności PON1.

Słowa kluczowe: paroksonaza, tętnica, żyła, tłuszcze, peroksydacja lipidów, choroba wieńcowa

\section{Introduction}

Atherosclerotic cardiovascular diseases are among the most common causes of morbidity and mortality in developed societies [1]. Coronary angiography is the clinical standard for the evaluation of patients with suspected atherosclerotic vascular disease [2]. Atherosclerotic vascular disease is characterized by deposition of cholesterol in and around cells of the arterial wall and the accumulation of inflammatory cells in the artery wall, in association with cellular proliferation and fibrosis [3]. Cholesterol is derived from plasma lipoproteins, low-density lipoprotein (LDL) in particular [4]. The atherosclerotic plaque occurs mainly in arteries, and rarely in veins. Different wall morphology, and/or changes in $\mathrm{pH}$, blood pressure, shear stresses and vascular tone have been considered responsible for the changes. The risk of coronary heart disease is related to the level of blood lipoproteins [5].

Human serum paraoxonase-1 (PON1) is synthesized in the liver and is closely associated with high-density lipoprotein (HDL) [6]. The enzyme hydrolyzes aryl esters such as paraoxon (0,0-diethyl-O-p-nitrophenylphosphate). Several studies have documented decreased PON1 activity in venous blood in some conditions associated with the development of premature atherosclerosis such as familial hypercholesterolemia and coronary artery disease [7, 8]. In addition, PON1 hydrolyzes lipid peroxides in atherosclerotic lesions, where they promote progression of atherogenesis [9]. There is evidence that low PON1 activity may be associated with accumulation of toxic aldehydes such as conjugated dienes (CD) and thiobarbituric acid-reactive substances (TBARS) [10]. Also, serum PON1 activity is low in subjects at increased risk of coronary artery disease (CA) [11].

Contradictory results have been obtained in literature evaluating the alterations of lipid concentrations in arterial and venous blood samples. Aviram et al. [12] reported low HDL-C and triglyceride (TG) levels in plasma from arterial blood of ten healthy males. Keidar et al. [13] found that LDL and HDL protein levels of five male patients were higher in arterial blood compared to venous blood samples. In contrast, Palmer et al. [14] found no difference in total cholesterol (TC), TG, LDL-C and HDL-C levels between arterial and venous samples. During coronary angiography, the percutaneous catheterization of various arteries is used in visualization of coronary arteries in human CAD studies.

\section{Aim}

We aimed to determine whether arterial blood samples withdrawn from femoral arteries during standard Judkin's technique can be used as well as venous blood samples for the evaluation of some biochemical parameters in coronary artery disease (CAD) patients and controls. Therefore, we investigated the changes in serum PON1 activity and the levels of serum lipids and lipid peroxidation markers (CD and TBARS) in arterial and venous blood samples of patients with and without CAD to determine whether any difference might explain why sclerosis occurs mainly in arteries but not in veins.

\section{Material and methods}

\section{Subjects}

The study subjects who underwent coronary angiography in the Cardiology Department were unrelated to each other. The ethnicity of the study population was homogeneous.

The standard Judkin's technique was used for coronary arteriographic examination, and images were interpreted by a panel of experienced cardiologists who were blinded to data on all biochemical analysis. The patients with a stenosis estimated as greater than $25 \%$ in at least one major epicardial artery were considered as CAD patients, whereas those without any detectable coronary artery anomaly were classified as controls.

The CAD group included 73 patients aged $56.6 \pm 1.17$ (median \pm SEM) years and comprised 63 men and 10 women. The control group consisted of 50 healthy $(25$ men and 25 women) unrelated people, aged $54 \pm 1.17$ years (median \pm SEM) years and randomly chosen.

Blood samples were drawn at 08:00 h, after $12 \mathrm{~h}$ of fasting, from the femoral artery and vena mediana cubiti. Serum samples were obtained by low speed centrifugation. All the tests were performed with fresh serum samples.

\section{Paraoxonase- 1 activity assay}

Serum PON1 activity was assayed spectrophotometrically as described previously [15] by using paraoxon as a substrate. One unit $(U)$ of PON1 activity was defined as $1 \mu \mathrm{mol}$ of $p$-nitrophenol formed per minute. Paraoxonase-1 activity was expressed as $\mathrm{U} / \mathrm{l}$. 
Table 1. PON1 activity, lipids, CD and TBARS levels, PON1/HDL-C, TC/HDL-C and LDL-C/HDL-C ratios in the serum of venous blood samples of patients with CAD and controls

Tabela 1. Aktywność PON1, stężenie lipidów, CD i TBARS oraz stosunek PON1/HDL-C, TC/HDL-C i LDL-C/HDL-C w osoczu z próbek krwi żylnej u pacjentów z CAD oraz u osób z grupy kontrolnej

\begin{tabular}{lccc} 
Parameters & $\begin{array}{c}\text { Controls } \\
(n=50)\end{array}$ & $\begin{array}{c}\text { CAD patients } \\
(n=73)\end{array}$ & $P_{3}$ \\
\hline PON1 $[\mathrm{U} / \mathrm{l}]$ & $309.51 \pm 22.59$ & $217.74 \pm 13.06$ & $<0.005$ \\
\hline $\mathrm{TC}[\mathrm{mg} / \mathrm{l}]$ & $193.40 \pm 5.51$ & $202.97 \pm 5.24$ & $\mathrm{NS}$ \\
\hline $\mathrm{LDL}-\mathrm{C}[\mathrm{mg} / \mathrm{dl}]$ & $122.94 \pm 4.75$ & $136.62 \pm 4.28$ & $<0.05$ \\
\hline $\mathrm{VLDL}-\mathrm{C}[\mathrm{mg} / \mathrm{dl}]$ & $26.20 \pm 1.43$ & $28.17 \pm 1.65$ & $\mathrm{NS}$ \\
\hline $\mathrm{TG}[\mathrm{mg} / \mathrm{dl}]$ & $131.04 \pm 7.13$ & $140.77 \pm 8.24$ & $\mathrm{NS}$ \\
\hline $\mathrm{HDL}-\mathrm{C}[\mathrm{mg} / \mathrm{dl}]$ & $43.02 \pm 1.30$ & $39.32 \pm 1.14$ & $<0.05$ \\
\hline PON1/HDL-C $[\mathrm{U} / \mathrm{mg}]$ & $0.73 \pm 0.05$ & $0.57 \pm 0.03$ & $<0.01$ \\
\hline TC/HDL-C & $4.63 \pm 0.15$ & $5.38 \pm 0.17$ & $<0.005$ \\
\hline LDL-C/HDL-C & $2.97 \pm 0.13$ & $3.64 \pm 0.14$ & $<0.005$ \\
\hline CD $[\mu \mathrm{mol} / \mathrm{l}]$ & $1.19 \pm 0.06$ & $1.85 \pm 0.06$ & $<0.001$ \\
\hline TBARS $[\mathrm{nmol} \mathrm{MDA} / \mathrm{l}]$ & $1.17 \pm 0.05$ & $1.60 \pm 0.04$ & $<0.001$
\end{tabular}

$C D$ - conjugated dienes, HDL-C-high-density lipoprotein cholesterol, $L D L-C$ - low-density lipoprotein cholesterol, NS - non-significant, $p_{3}-p$ values for comparison of vein of controls $v$ s. vein of patients with CAD and artery of controls, PON1 - paraoxonase-1, TBARS - thiobarbituric acid-reactive substances, TC - total cholesterol, TG - triglycerides, VLDL-C - very low-density lipoprotein cholesterol, vs. artery of patients with CAD. Values represent mean \pm SEM. Experimental procedures are described in the text

$C D$ - zwiazzane dieny, HDL-C-cholesterol lipoprotein o wysokiej gęstości, LDL-C - cholesterol lipoprotein o matej gęstości, NS - brak istotności, $p_{3}$ - wartości $p$ dla porównania krwi żylnej osób z grupy kontrolnej i pacjentów z CAD lub krwi tętniczej osób z grupy kontrolnej i pacjentów z CAD, PON1 - paraoksonaza 1, TBARS - substancje reagujace z kwasem tiobarbiturowym, TC - cholesterol catkowity, TG triglicerydy, VLDL-C - cholesterol lipoprotein o bardzo matej gestości. Wartości reprezentuja średnia \pm SEM. Metody analiz opisano w tekście

\section{Lipid assays}

Serum TC, HDL-C and TG levels were assayed on an Abbott Aeroset auto-analyzer (Abbott Aeroset System Laboratories, Abbott Park, IIl., USA) using enzymatic colorimetric methods. The LDL-C fraction was calculated indirectly, using the Friedewald equation [16]. The factor [triglyceride]/5 was used to estimate the VLDL-C concentration [16].

\section{Conjugated dienes assay}

Serum CD levels were measured by the method of Recknagel and Glende [17]. The results were expressed as $\mu \mathrm{mol}$ hydroperoxide/l using the extinction coefficient $\left(\varepsilon=2.52 \times 10^{4} \mathrm{M}^{-1} \mathrm{~cm}^{-1}\right)$.
Table 2. Comparison of PON1 activity, lipids, CD and TBARS levels, PON1/HDL-C, TC/HDL-C and LDL-C/ HDL-C ratios in the serum of arterial blood samples of patients with CAD and controls

Tabela 2. Aktywność PON1, stężenie lipidów, CD i TBARS oraz stosunek PON1/HDL-C, TC/HDL-C i LDL-C/HDL-C W osoczu z próbek krwi tętniczej u pacjentów z CAD oraz u osób z grupy kontrolnej

\begin{tabular}{lccc} 
Parameters & $\begin{array}{c}\text { Controls } \\
(n=50)\end{array}$ & $\begin{array}{c}\text { CAD patients } \\
(n=73)\end{array}$ & $P_{3}$ \\
\hline PON1 $[\mathrm{U} / \mathrm{ll}]$ & $274.68 \pm 21.61$ & $190.69 \pm 12.31$ & $<0.005$ \\
\hline TC $[\mathrm{mg} / \mathrm{dl}]$ & $184.08 \pm 5.33$ & $194.53 \pm 5.08$ & $\mathrm{NS}$ \\
\hline $\mathrm{LDL}-\mathrm{C}[\mathrm{mg} / \mathrm{dl}]$ & $117.76 \pm 4.77$ & $132.11 \pm 4.16$ & $<0.05$ \\
\hline VLDL-C $[\mathrm{mg} / \mathrm{dl}]$ & $24.05 \pm 1.33$ & $26.41 \pm 1.48$ & $\mathrm{NS}$ \\
\hline TG $[\mathrm{mg} / \mathrm{dl}]$ & $120.34 \pm 6.57$ & $134.14 \pm 7.15$ & $\mathrm{NS}$ \\
\hline $\mathrm{HDL}-\mathrm{C}[\mathrm{mg} / \mathrm{dl}]$ & $41.62 \pm 1.20$ & $36.84 \pm 1.12$ & $<0.01$ \\
\hline $\mathrm{PON} 1 / \mathrm{HDL}-\mathrm{C}[\mathrm{U} / \mathrm{mg}]$ & $0.67 \pm 0.05$ & $0.53 \pm 0.03$ & $<0.05$ \\
\hline TC/HDL-C & $4.54 \pm 0.15$ & $5.55 \pm 0.20$ & $<0.001$ \\
\hline LDL-C/HDL-C & $2.92 \pm 0.13$ & $3.78 \pm 0.15$ & $<0.001$ \\
\hline $\mathrm{CD}[\mu \mathrm{mol} / \mathrm{l}]$ & $1.23 \pm 0.06$ & $2.04 \pm 0.07$ & $<0.001$ \\
\hline TBARS $[\mathrm{nmol} \mathrm{MDA} / \mathrm{l}]$ & $1.21 \pm 0.06$ & $1.75 \pm 0.03$ & $<0.001$
\end{tabular}

Abbreviations are as in Table 1.

Skróty jak w tabeli 1.

\section{Thiobarbituric acid-reactive substances assay}

The levels of TBARS were measured by a fluorometric method described by Wasowicz et al. [18] and Gumuslu et al. [19] using 1,1,3,3-tetramethoxypropane as standard, and the results were expressed as nmol malondialdehyde $(\mathrm{MDA}) / \mathrm{l}$.

\section{Statistical analysis}

All statistical analyses were performed using the statistical package SPSS for Windows, Version 15.0.0 (SPSS, Chicago, IL). All values were expressed as mean \pm SEM. To test the difference between given parameters measured in serum of venous and arterial blood of the same group, the parametric "paired-samples $t$-test" was applied. Comparisons between controls and CAD patients were made by Student's t-test. Pearson's correlation coefficient was used to test the strength of any associations between different variables. Values of $p$ below 0.05 was considered to be statistically significant.

\section{Results}

The preliminary data of all parameters from patients with CAD and healthy individuals are reported in Tables 1 and 2.

There was no statistical difference between arterial versus venous blood samples both in controls and CAD patients in PON1 activity, TC, LDL-C, VLDL-C, HDL-C, TG, CD 
and TBARS concentrations, and TC/LDL-C, LDL-C/HDL-C and PON1/HDL-C ratios ( $p>0.05)$.

In venous and arterial blood samples, serum PON1 activity $(p<0.005$ and $p<0.005)$, HDL-C levels $(p<0.05$ and $p<0.01$ ) and PON1/HDL-C ratios $(p<0.01$ and $p<0.05)$ were significantly higher in controls than in patients with CAD. Also, in venous and arterial blood samples, the mean LDL-C $(p<0.05$ and $p<0.05), \mathrm{CD}(p<0.001$ and $p<0.001)$ and TBARS $(p<0.001$ and $p<0.001)$ concentrations, and TC/HDL-C $(p<0.005$ and $p<0.001)$ and LDL-C/HDL-C $(p<0.005$ and $p<0.001)$ ratios were significantly lower in controls than in CAD patients.

Serum TC levels in venous blood of the control group were significantly correlated to serum LDL-C $(r=0.904$, $p<0.001)$, VLDL-C $(r=0.401, p<0.01)$, HDL-C $(r=0.319$, $p<0.05)$ and TG $(r=0.401, p<0.01)$ levels. TC levels in venous blood of CAD patients were correlated to LDL-C $(r=0.934, p<0.001)$, VLDL-C $(r=0.452, p<0.001), \mathrm{HDL}-\mathrm{C}$ $(r=0.449, p<0.001)$ and TG $(r=0.453, p<0.001)$ levels (Table 2). HDL-C levels in venous blood of CAD patients were correlated to PON1 activity $(r=0.246, p<0.05)$. A positive correlation was observed between CD and TBARS concentrations in venous blood of CAD patients $(r=0.347$, $p<0.01)$.

Serum TC levels in arterial blood of the control group were significantly correlated to serum LDL-C $(r=0.915$, $p<0.001)$, VLDL-C $(r=0.464, p<0.001)$, HDL-C $(r=0.377$, $p<0.01)$ and TG $(r=0.491, p<0.001)$ levels. TC levels in arterial blood of CAD patients were significantly correlated to LDL-C $(r=0.928, p<0.001)$, VLDL-C $(r=0.342$, $p<0.05)$, HDL-C $(r=0.318, p<0.05)$ and TG $(r=0.345$, $p<0.05$ ) levels (Table 3). HDL-C levels in arterial blood of the control group were correlated to PON1 activity $(r=0.316, p<0.01)$, while the correlation was not significant in venous samples of the control group. A correlation was observed between CD and TBARS concentrations in arterial blood of the control group $(r=0.287, p<0.05)$.

In venous blood samples taken from control and CAD patient groups, serum levels of LDL-C, TG, VLDL-C, HDL-C,

Table 3. Correlation coefficients between TC and LDL-C, VLDL-C, HDL-C and TG

Tabela 3. Wspótczynniki korelacji między TC i LDL-C, VLDL-C, HDL-C i TG

\begin{tabular}{lcccc} 
& \multicolumn{2}{c}{ Venous blood } & \multicolumn{2}{c}{ Arterial blood } \\
\cline { 2 - 5 } & Control & CAD patients & Control & CAD patients \\
\cline { 2 - 5 } & TC & TC & TC & TC \\
\hline LDL-C & $0.904^{* * *}$ & $0.934^{* * *}$ & $0.915^{* *}$ & $0.928^{* *}$ \\
\hline VLDL-C & $0.401^{* *}$ & $0.452^{* * *}$ & $0.464^{* *}$ & $0.342^{* *}$ \\
\hline HDL-C & $0.319^{*}$ & $0.449^{* * *}$ & $0.377^{* *}$ & $0.318^{* *}$ \\
\hline TG & $0.401^{* *}$ & $0.453^{* * *}$ & $0.491^{* *}$ & $0.345^{* *}$ \\
Abbreviations are as in Table I. ${ }^{*} p<0.05,{ }^{* *} p<0.01,{ }^{* * *} p<0.01$ \\
\multicolumn{3}{c}{ Skróty jak w tabelil. ${ }^{*} p<0.05,{ }^{* *} p<0.01,{ }^{* * *} p<0.01$}
\end{tabular}

CD and TBARS were positively correlated with arterial blood samples.

The CD levels in venous blood of CAD patients were significantly correlated to TC $(r=-0.255, p<0.05)$ and LDL-C $(r=-0.259, p<0.05), \mathrm{CD}(r=0.757, p<0.001)$ and TBARS $(r=0.242, p<0.05)$ levels in arterial blood of CAD patients.

On multiple logistic regression analysis, risk factors associated with CAD included arterial $C D$, venous $C D$, arterial TBARS and LDL-C/HDL-C when CAD patients were assayed against controls.

\section{Discussion}

This is the first report evaluating the differences in serum PON1 activity, lipids and lipid peroxidation markers in arterial blood of patients with CAD and controls. No comparable report is available in the literature on the activity of PON1, lipids and lipid peroxidation levels in serum of arterial blood of patients with CAD and controls.

Our study demonstrated no difference in PON1 activities or lipid and lipid peroxidation levels in blood samples derived from the arteries in comparison to those derived from veins in patients with CAD. Nevertheless, these results are not enough to explain why atherosclerotic plaques occur in arteries but not veins [12]. There is evidence that a decrease in HDL-associated PON1 activity may be associated with an increased risk of arterial lesion formation [11], whereas HDL has been shown to be an independent risk factor for atherosclerosis [20, 21]. In this study, we observed decreased serum PON1 activity and HDL-C concentrations in venous and arterial blood samples of patients with CAD when compared to healthy controls. This result agrees with our [15] and other previously published data in patients with coronary heart disease, who have low PON1 activity and low HDL-C concentration in venous blood [20, 21]. The decrement in PON1 activity in arterial and venous blood of patients with CAD may be due to the inactivation of the enzyme by lipid peroxidation products. In the present study, we observed that the lipid peroxidation products (CD and TBARS) were higher in arterial and venous blood of patients with CAD. HDL-C associated PON1 may be a major defense barrier against lipid peroxides from oxidized LDLs. In fact, the ability of HDL to attenuate the oxidation of LDL is largely attributed to PON1 [22]. Besides lipid peroxides, PON1 has been found to hydrolyze hydrogen peroxides, which are a major reactive oxygen species produced by the arterial wall during atherogenesis [23].

A low plasma $\mathrm{HDL}-\mathrm{C}$ concentration is an important risk factor for CAD [24]. To assess whether the altered PON1 activity was due to the decreased HDL concentration, we standardized the enzyme activity for HDL-C concentration (PON1/HDL-C ratio) and found it lower in venous and arterial blood samples of CAD patients when compared to controls. This suggested that PON1 activity changes are not 
entirely dependent on HDL concentration in this patient group, but may be due to some as yet undetermined factors. Paraoxonase-1 activity can change independently of the HDL-C concentration [25]. The decrement in PON1 activity in CAD patients may be due to the decreased synthesis of the enzyme or increased degradation of the enzyme. Ayub et al. [6] have reported that low PON1 activity in patients with myocardial infarction was most likely due to a decrease in serum PON1 concentration.

In the present report, PON1 activity is significantly correlated with $\mathrm{HDL}-\mathrm{C}$ concentration in serum of venous and arterial blood of patients with CAD. However, there was not a statistically significant correlation between PON1 activity and $\mathrm{HDL}-\mathrm{C}$ concentration in venous blood of the control group. This is in accordance with the results of Schiavon et al. [7]. This conclusion is inconsistent with previous reports of a weak statistically significant correlation between PON1 activity and HDL-C concentration in venous blood of the control population [25].

Serum concentrations of TC, LDL-C, VLDL-C, TG and $\mathrm{HDL}-\mathrm{C}$ were not statistically different in arterial blood than in venous blood of 73 patients (ages 34-79 years, 63 men, 10 women) with CAD. Our results confirm the results of Palmer et al. [14] and Yu et al. [26]. Palmer et al. [14] (26 patients, ages 39-84 years, 54\% men) did not find any significant difference in the concentrations of TC, TG, HDL-C and LDL-C. In another study, Yu [26] found no difference in TC and HDL-C concentrations in 42 subjects with peripheral arterial disease. On the other hand, Keidar et al. [13] found that LDL-C concentration was higher in arterial blood compared to venous blood of 5 male patients (ages 35-60 years) undergoing coronary angiography but did not find any difference in TC and TG concentrations. These discrepancies may be due to the differences in sex, age and number of subjects, differences in methodologies for lipid determination, environmental conditions, diet and the genetic architecture of the study population.

We observed significantly lower concentrations of LDL-C and higher concentrations of HDL-C in venous and arterial blood samples of controls compared with CAD patients. Epidemiological evidence has revealed that LDL concentration is related directly with the risk of developing CAD, and $\mathrm{HDL}$ is inversely related to CAD risk [27]. Our results are consistent with previous reports [20].

The various LDL oxidation pathways produce several lipid peroxidation products such as lipid peroxides and aldehydes [28]. An important indicator of lipid peroxidation is $C D$, which is formed by the molecular rearrangement of the carbon-centered radicals. Another particular product, MDA, is an important biomarker of lipid peroxidation [19]. We have quantified MDA by the thiobarbituric acid (TBA) test. But, TBA also can react with a wide range of other substances. It is more accurate to use the term TBARS instead of MDA for the products of the reaction with TBA [18]. One single assay of lipid peroxidation is probably not sufficient to serve as a marker for cardiovascular risk, and there is a need for measuring several markers [28]. In this study, CD and TBARS were measured as markers of lipid peroxidation. Increases in CD and TBARS levels in serum of venous and arterial blood of patients with CAD suggested increased production of lipid peroxidation. The results obtained for TBARS levels are consistent with recently published observations which showed increased TBARS levels in patients with CAD [29-31]. However, Halevy et al. [32] found no change in TBARS levels of CAD patients. The reason for these contradictory results might be the use of different methods for determination of TBARS levels or differences in sex and age of subjects. No comparable report is available in the literature on the levels of $C D$ in patients with CAD. The increase observed in the CD and TBARS concentrations of patients with CAD is a good indicator of increased lipid peroxidation. Our data support the conclusion that lipid peroxidation occurs in patients with CAD.

This study was limited by the relatively small number of cases examined and the lack of details about the genetic architecture of the study population and the effect of gender.

\section{Conclusions}

The present study demonstrates that in CAD patients and controls having coronary angiography, PON1 activity and the levels of lipids and lipid peroxidation markers are not altered in arterial blood samples. If necessary, arterial blood samples can also be used as well as venous samples to determine these parameters. On the other hand, arterial lipid peroxidation markers were correlated with $C A D$ and were also found to be major risk factors for CAD. The data suggest that enhanced lipid peroxidation products may be important factors influencing the development of coronary artery disease.

\section{Acknowledgments}

A part of this work was supported by a grant from the Akdeniz University Research Foundation (Project Number: 99.02.0122.04).

\section{References}

1. Graham I. What impact will current trial data have on future guideline recommendations? Am J Med 2005; 118 Suppl 12A: 42-47.

2. Little WC, Constantinescu M, Applegate RJ, et al. Can coronary angiography predict the site of a subsequent myocardial infarction in patients with mild-to-moderate coronary artery disease? Circulation 1988; 78: 1157-1166.

3. Blanco-Colio LM, Martin-Ventura JL, Vivanco F, et al. Biology of atherosclerotic plaques: what we are learning from proteomic analysis. Cardiovasc Res 2006; 72: 18-29.

4. Costet P. Molecular pathways and agents for lowering LDL-cholesterol in addition to statins. Pharmacol Ther 2010; 126: 263-278. 
5. Torzewski M, Lackner KJ. Initiation and progression of atherosclerosis: enzymatic or oxidative modification of low-density lipoprotein? Clin Chem Lab Med 2006; 44: 1389-1394.

6. Ayub A, Mackness MI, Arrol S, et al. Serum paraoxonase after myocardial infarction. Arterioscler Thromb Vasc Biol 1999; 19: 330-335.

7. Schiavon R, De Fanti E, Giavarina D, et al. Serum paraoxonase activity is decreased in uremic patients. Clin Chim Acta 1996; 247 71-80.

8. Mackness MI, Durrington PN, Ayub A, Mackness B. Low serum paraoxonase: a risk factor for atherosclerotic disease? Chem Biol Interact 1999; 119-120: 389-397.

9. Gocmen AY, Sahin E, Semiz E, Gumuslu S. Is elevated serum ceruloplasmin level associated with increased risk of coronary artery disease? Can J Cardiol 2008; 24: 209-212.

10. Gocmen AY, Sahin E, Kocak H, et al. Levels of asymmetric dimethylarginine, nitric oxide and lipid peroxidation markers in patients with end-stage renal disease having peritoneal dialysis treatment. Clin Biochem 2008; 41: 836-840.

11. Oda MN, Bielicki JK, Berger T, Forte TM. Cysteine substitutions in apolipoprotein $\mathrm{A}-\mathrm{I}$ primary structure modulate paraoxonase activity. Biochemistry 2001; 40: 1710-1718.

12. Aviram M, Viener A, Brook JG. Reduced plasma high-density lipoprotein and increased platelet activity in arterial versus venous blood. Postgrad Med J 1987; 63: 91-94.

13. Keidar S, Aviram M, Grenadier E, et al. Arterial blood derived low density lipoprotein increases platelet aggregation and macrophage cholesterol content in comparison to lipoprotein derived from veinous blood. Arter 1989; 16: 62-71.

14. Palmer B, Watson LE, Riggs MW, et al. Comparison of lipid and non-lipid markers of atherosclerosis in arterial versus venous blood. Ann Clin Biochem 2003; 40: 286-288.

15. Gocmen AY, Gumuslu S, Semiz E. Association between paraoxonase-1 activity and lipid peroxidation indicator levels in people living in the Antalya region with angiographically documented coronary artery disease. Clin Cardiol 2004; 27: 426-430.

16. Friedewald WT, Levy RI, Fredrickson DS. Estimation of the concentration of low-density lipoprotein cholesterol in plasma, without use of the preparative ultracentrifuge. Clin Chem 1972; 18: 499-502.

17. Recknagel RO, Glende EA, Jr. Spectrophotometric detection of lipid conjugated dienes. Methods Enzymol 1984; 105: 331-337.

18. Wasowicz W, Neve J, Peretz A. Optimized steps in fluorometric determination of thiobarbituric acid-reactive substances in serum: importance of extraction $\mathrm{pH}$ and influence of sample preservation and storage. Clin Chem 1993; 39: 2522-2526.

19. Gumuslu S, Serteser M, Ozben T, et al. Inhibitory role of N omeganitro-L-arginine methyl ester (L-NAME), a potent nitric oxide synthase inhibitor, on brain malondialdehyde and conjugated diene levels during focal cerebral ischemia in rats. Clin Chim Acta 1997; 267: 213-223.

20. Pan JP, Chiang AN, Tai JJ, et al. Restriction fragment length polymorphisms of apolipoprotein $B$ gene in Chinese population with coronary heart disease. Clin Chem 1995; 41: 424-429.

21. McElveen J, Mackness MI, Colley CM, et al. Distribution of paraoxon hydrolytic activity in the serum of patients after myocardial infarction. Clin Chem 1986; 32: 671-673.

22. Mackness MI, Arrol S, Abbott C, Durrington PN. Protection of lowdensity lipoprotein against oxidative modification by high-density lipoprotein associated paraoxonase. Atherosclerosis 1993; 104: 129-135.
23. Aviram M, Rosenblat M, Bisgaier CL, et al. Paraoxonase inhibits high-density lipoprotein oxidation and preserves its functions. A possible peroxidative role for paraoxonase. J Clin Invest 1998; 101: 1581-1590.

24. Pascot A, Lemieux I, Bergeron J, et al. HDL particle size: a marker of the gender difference in the metabolic risk profile. Atherosclerosis 2002; 160: 399-406.

25. Mackness MI, Harty D, Bhatnagar D, et al. Serum paraoxonase activity in familial hypercholesterolaemia and insulin-dependent diabetes mellitus. Atherosclerosis 1991; 86: 193-199.

26. Yu IA. Arteriovenous lipid content difference in patients with atherosclerosis. Cor Vasa 1985; 27: 304-309.

27. Mackness MI, Arrol S, Durrington PN. Paraoxonase prevents accumulation of lipoperoxides in low-density lipoprotein. FEBS Lett 1991; 286: 152-154.

28. Aviram M. Review of human studies on oxidative damage and antioxidant protection related to cardiovascular diseases. Free Radic Res 2000; 33: S85-S97.

29. Avogaro A, Armigliato M, Cazzolato G, et al. Lipid peroxidation and LDL modifications in nondiabetic patients with ischemic heart disease: the role of insulin action. G Ital Cardiol 1996; 26: 169-175.

30. Charan Sahoo K, Arora S, Goyal S, et al. Cardioprotective effects of benazepril, an angiotensin-converting enzyme inhibitor, in an ischaemia-reperfusion model of myocardial infarction in rats. J Renin Angiotensin Aldosterone Syst 2009; 10: 201-209.

31. Hoshiga M, Arishiro K, Nakakoji T, et al. Switching to aggressive statin improves vascular endothelial function in patients with stable coronary artery disease. J Atheroscler Thromb 2010; 17: 705-711.

32. Halevy D, Thiery J, Nagel D, et al. Increased oxidation of LDL in patients with coronary artery disease is independent from dietary vitamins E and C. Arterioscler Thromb Vasc Biol 1997; 17: 1432-1437. 